\title{
Pengaruh Karakteristik Pekerjaan dan Motivasi Kerja Terhadap Kepuasan Kerja dan Kinerja Pegawai Negeri Sipil
}

\author{
Emy Fibrianti ${ }^{1}$, Zainal Ilmi ${ }^{2}$, Warsilan ${ }^{3}$ \\ Fakultas Ekonomi dan Bisnis Universitas Mulawarman, Samarinda ${ }^{1,2,3}$ \\ Email: emy.fibrianti@gmail.com
}

\begin{abstract}
This study aims to analyze and find out several factors that can affect job satisfaction and employee performance, variables used in this study are job characteristics, work motivation, job satisfaction, and employee performance, The sample in this study were employees found in the Samarinda Research and Industrial Standardization Center with a total sample of 49 respondents with the data collection method used to distribute questionnaires. Researchers use SPSS as a tool for processing existing data. The results showed that the variable job characteristics have a positive and significant effect both on the variable of job satisfaction and on employee performance variables, work motivation variables have a positive and significant effect on job satisfaction but do not have a positive and significant effect on employee performance, and for job satisfaction variables has a positive and significant effect on employee performance.
\end{abstract}

Keywords: job characteristics, motivation, job satisfaction, performance

\section{Pendahuluan}

Pelayanan publik yang dilakukan oleh aparatur pemerintah saat ini belum memenuhi harapan masyarakat. Hal ini dapat diketahui dari berbagai keluhan masyarakat yang disampaikan melalui media masa dan jaringan sosial, sehingga memberikan dampak buruk terhadap pelayanan pemerintah, yang menimbulkan ketidakpercayaan masyarakat.

Penilaian terhadap Indeks Kepuasan Masyarakat ini sangat penting karena dijadikan sebagai salah satu indikator penilaian oleh Menpan-RB untuk pembagunan Zona Integritas menuju Wilayah Bebas Korupsi (WBK) dan Wilayah Birokrasi Bersih dan Melayani (WBBM) yang merupakan bagian dari reformasi birokrasi, dimana salah satu persyaratan unit kerja dapat diusulkan sebagai WBBM nilai SKM harus rata-rata diatas 3,6 atau kategori sangat memuaskan. Hal yang menjadi perhatian utama atas hasil survei tersebut, adalah harus ada saran perbaikan 
dari pemberi layanan yang disurvei terhadap peningkatan kualitas layanan NEGARA et al., (2014).

Selain dari hasil evaluasi survey IKM, observasi awal yang dilakukan terhadap kinerja pelayanan publik, diketahui bahwa kinerja pegawai Baristand Industri Samarinda masih belum menunjukkan hasil yang maksimal, ditunjukkan dengan tidak tercapainya target penyelesaian sesuai dengan Standar Pelayanan Minimal yaitu 14 hari kerja (sesuai target dalam sasaran mutu). Kreatifitas dan motivasi pegawai terhadap penyelesaian perkerjaan dirasa masih kurang. Selain itu juga terlihat seringnya terjadi keluhan dari para analis laboratorium terkait lambatnya manajemen dalam merespon permintaan kebutuhan penunjang pelaksanaan pengujian serta lambatnya respon dalam penyelesaian pekerjaan.

Lingkup dan karakteristik pekerjaan sebagai seorang analis laboratorium memerlukan keterampilan dan pengetahuan yang dituntut terus berkembang. Hal ini sejalan dengan perkembangan permasalahan dan penomena dilapangan serta kebijakan-kebijakan yang dikeluarkan pemerintah. Tuntutan pekerjaan yang cukup tinggi dan tuntutan pelayanan yang harus diberikan seringkali tidak sejalan dengan ketersediaan sumber daya terutama untuk sumber daya manusia.

Fenomena lain yang terjadi adalah adanya terdapat beberapa pegawai menyatakan bahwa mereka cukup puas dengan hasil pekerjaan mereka walaupun terkadang berada dalam situasi dibawah tekanan dalam waktu penyelesaian. Alasan yang diberikan walaupun beban kerja yang cukup tinggi namun mereka tetap bersemangat karena adanya tuntutan tanggung jawab yang besar untuk menafkahi keluarganya. Namun fenomena lain yang akhir-akhir ini terjadi adalah dengan naiknya tunjangan kinerja pekerja tidak signifikan berdampak pada tingkat penyelesaian pekerjaan, bertolak belakang dengan teori kompensasi dari Werther dan Davis dalam Wibowo (2016), kompensasi merupakan sesuatu yang diterima pekerja sebagai imbalan atas kontribusi/jasanya kepada organisasi.

Kepuasan kerja merupakan salah satu faktor yang perlu diperhatikan untuk mendorong kinerja individu yang berkualitas. Menurut Mariniharsi (2017), kepuasan kerja sangat dipengaruhi dari pekerjaan itu sendiri, yang mana didalam pekerjaan tersebut mengandung beberapa tingkatan dimensi. Pegawai yang 
memiliki kepuasan kerja akan memandang pekerjaan bukan sebagai beban melainkan sebagai suatu yang menyenangkan. Berbeda dengan yang memiliki kepuasan rendah akan melihat pekerjaan tersebut sebagai beban dan membosankan sehingga merasa terpaksa dalam menyelesaikan tugasnya.

\section{Tinjauan Pustaka}

\subsection{Manajemen Sumber Daya Manusia}

Menurut Susilo, (2002), manajemen SDM adalah HRM refers to policies, practices and systems that influence employees behavior, attitudes, and performance (manajemen sumber daya manusia mengacu kebijakan, pelaksanaan dan sistem yang menpengaruhi perilaku, sikap dan kinerja karyawan).

Menurut Bintoro 2017), menyatakan bahwa "Manajemen sumber daya manusia, disingkat MSDM, adalah suatu ilmu atau cara bagaimana mengatur hubungan dan peranan sumber daya (tenaga kerja) yang dimiliki oleh individu secara efisien dan efektif serta dapat digunakan secara maksimal sehingga tercapai tujuan bersama perusahaan, karyawan dan masyarakat menjadi maksimal".

Serangkaian proses, strategi dan aktivifas yang didesain secara efektif melalui pengintegrasian seluruh sumber daya yang ada pada organisasi agar berfungsi secara maksimal untuk mencapai tujuannya, Siagian, 2017).

Tujuan umum manajemen sumber daya manusia adalah untuk memastikan bahwa organisasi mampu mengelola orang-orang yang terlibat didalamnya mulai dari perencanaan, pengorganisasian, pelaksanaan dan pengawasan dalam rangka pencapaian tujuan organisasi. Menurut Mulyadi (2018), agar tujuan organisasi dan tujuan individu dapat tercapai secara selaras dan harmonis maka diperlukan kerjasama dan usaha yang sungguh-sungguh dari kedua pihak (pengurus organisasi dan anggota organisasi) untuk bersama-sama berusaha saling memenuhi kewajiban masing-masing secara bertanggung jawab, sehingga pada saat masing-masing mendapatkan haknya dan dapat memenuhi rasa keadilan baik bagi anggota organisasi/ pegawai maupun bagi pengurus organisasi/ pejabat yang berwenang.

\subsection{Kinerja Pegawai}

Menurut Mulyani \& Soliha (2014), dalam penelitiannya mengatakan bahwa kinerja menggambarkan bagaimana perilaku kerja seseorang dalam menjalankan 
peran dan fungsinya didalam suatu organisasi ataupun instansi. Pada kenyataannya beberapa faktor banyak mempengaruhi perilaku orang tersebut, sehingga bila diterapkan maka dapat menjadi dasar untuk menganalisis latar belakang yang mempengaruhi kinerja.

Sedangkan menurut Wibowo (2016) mengemukakan klasifikasi ukuran yang digunakan dalam kinerja sebagai berikut:

1) Produktivitas yaitu merupakan hubungan antara jumlah output yang dihasilkan dibandingkan dengan sumber daya yang digunakan dalam menghasilkan produk/ output tersebut.

2) Kualitas yaitu mutu kerja seseorang yang dikaitkan dengan kesesuaian antara rencana kerja dengan sasaran atau tujuan dari organisasi. Penilaian kualitas kerja dapat dilihat dari ukuran internal seperti jumlah tolak, produk cacat dan ukuran eksternal kepuasan pelanggan atau frekuensi pemesan ulang pelanggan.

3) Ketepatan waktu yaitu ukuran atau target waktu yang ditetapkan dalam menyelesaikan suatu pekerjaan mulai dari proses hingga akhir.

4) Cycle time yaitu waktu yang diperlukan dari satu proses ke proses berikutnya. Pengukuran cycle time mengukur seberapa lama waktu yang digunakan untuk sesuatu yang dilakukan.

5) Pemanfaatan sumber daya yaitu pengukuran antara sumber daya yang dipergunakan dengan ketersediaan sumber daya yang dimiliki. Dengan mengetahui tingkat pemanfaatan sumber daya maka organisasi dapat menentukan kebutuhan sumber daya.

\subsection{Kepuasan Kerja}

Menurut Siagian (2005), bahwa "karyawan yang puas tidak selalu mencerminkan mereka berprestasi/ berkinerja tinggi, begitu pula seseorang yang merasa puas belum tentu termotivasi untuk berprestasi tinggi karena rasa kepuasannya tidak terletak pada motivasinya tetapi cendrung karena imbalan yang akan diperolehnya. Untuk itu dapat disimpulkan bahwa tidak selalu ada kaitan antara kepuasan kerja dengan prestasi tergantung pada apa yang dimaksud dengan kepuasan kerja itu sendiri”.

Kepuasan kerja mencerminkan perasaan dan sikap positif seseorang terhadap 
pekerjaannya dengan segala sesuatu yang dihadapi dilingkungan kerjanya baik internal maupun eksternal. Seseorang dapat merasa puas terhadap salah satu aspek dari pekerjaannya dan terkadang pula merasa tidak puas terhadap salah satu aspek lainnya dari pekerjaan tersebut. Pandangan bahwa pekerja yang merasa puas terhadap pekerjaannya umumnya lebih produktif dari pada yang merasa tidak puas menjadi acuan bagi banyak manajer ataupun pimpinan. Sehingga dapat dikatakan bahwa kepuasan kerja suatu hal yang kompleks dan multifaktorial yang cukup kompleks dalam mencapai dan meningkatkannya karena didalamnya mengandung kolaborasi antara karyawan dengan karyawan, karyawan dengan atasan dan karyawan dengan orang lain Subudi et al., (2015).

Wibowo (2016) terdapat hubungan antara kepuasa kerja dengan variabel lain dimana bisa berupa hal yang postif ataupun bahwa manajemen dapat mempengaruhi dengan signifikan variabel lainnya dengan meningkatkan kepuasan kerja.

\subsection{Motivasi}

Hasibuan \& Hasibuan (2016), menyatakan motivasi mempersoalkan bagaimana cara mengarahkan daya dan potensi agar bekerja mencapai tujuan yang ditentukan. Pada dasarnya seorang bekerja karena keinginan memenuhi kebutuhan hidupnya. Dorongan keinginan pada diri seseorang dengan orang yang lain berbeda sehingga perilaku manusia cenderung beragam di dalam bekerja.

Pada dasarnya motivasi mengarahkan bagaimana kita bisa mendorong gairah kerja karyawan untuk bekerja keras sehingga dapat mencapai tujuan yang mereka harapkan. Hal ini akan meningkatkan produkitvitas kerja karyawan sehingga berpengaruh pada pencapaian tujuan perusahaaan ataupun organisasi. Saleem et al (2010) mengungkapkan motivasi sebagai suatu dorongan yang akan menggerakkan seseorang untuk menghasilkan suatu yang terbaik dari kegiatan yang telah dilakukan secara maksimal. Menurut Wibowo, (2016) "terdapat kepentingan bersama antara manusia sebagai pekerja dengan organisasi. Pekerja disatu sisi melakukan pekerjaan mengharapkan kompensasi untuk pemenuhan kebutuhannya dan disisi lainnya untuk mencapai tujuan pribadinya untuk mewujudkan prestasi kerjanya. Sedangkan kinerja organisasi diwujudkan oleh kumpulan kinerja dari 
semua pekerja untuk mencapai tujuan organisasi”.

"Berkaitan dengan pentingnya manusia dalam organisasi dapat dikatan bahwa pada dasarnya perilaku manusia itu ditentukan oleh keinginannya untuk dapat mencapai beberapa tujuan yang dikenal dengan istilah "motivasi" . Dengan demikian motivasi pada diri manusia merupakan suatu faktor terkuat yang akan mempengaruhi perilakunya yang kemudian dibawanya dalam kehidupan berorganisasi, Mulyadi (2018).

Terdapat banyak pengertian tentang motivasi, diantaranya adalah, Kinicki \& Kreitner, (2006) yang menyatakan bahwa "motivasi adalah kekuatan internal dan eksternal yang mengarahkan individu untuk bekerja mencapai tujuannya”.

\section{Metode Penelitian}

Penelitian ini dilakukan dengan mengambil obyek penelitian pada Kantor Balai Riset dan Standardisasi Industri Samarinda (Baristand Industri Samarinda).

Populasi yang diambil dalam penelitian ini adalah seluruh pegawai Baristand Industri Samarinda sebanyak 49 responden dan sampel yang digunakan adalah keseluruhan dari populasi yang ada, yang berjumlah 49 responden.

Penelitian ini menggunakan data dari jawaban responden terhadap kuesioner yang disebarkan sebelumnya dengan indikasi jawaban menggunakan skala likert.

Sumber data yang digunakan dalam penelitian ini adalah data primer dan sekunder.

\section{Hasil Dan Pembahasan}

\section{1) Uji Validitas}

Tabel 1. Hasil uji validitas variabel karakteristik pekerjaan (X1)

\begin{tabular}{lll}
\hline Keterangan & Nilai Perolehan & Tingkat Validitas \\
\hline X1.1 & 0,705 & 0,3 \\
X1.2 & 0,726 & 0,3 \\
X1.3 & 0,775 & 0,3 \\
X1.4 & 0,827 & 0,3 \\
X1.5 & 0,775 & 0,3 \\
\hline
\end{tabular}

Sumber: data diolah 2020

Berdasarkan output pada tabel diatas, dari keseluruhan item yang digunakan pada variabel karakteristik kerja perolehan nilai t hitungnya berada di atas 0,3 , sehingga dapat dikatakan item 1 sampai 5 adalah valid. 
Tabel 2. Hasil uji validitas variabel motivasi kerja (X2)

\begin{tabular}{lll}
\hline Keterangan & Nilai Perolehan & Tingkat Validitas \\
\hline X2.1 & 0,787 & 0,3 \\
X2.2 & 0,729 & 0,3 \\
X2.3 & 0,796 & 0,3 \\
X2.4 & 0,701 & 0,3 \\
\hline
\end{tabular}

Sumber: data diolah 2020

Berdasarkan output pada tabel di atas, dari keseluruhan item yang digunakan pada variabel motivasi kerja perolehan nilai t hitungnya berada di atas 0,3 , sehingga dapat dikatakan item 1 sampai 4 adalah valid.

Tabel 3. Hasil uji validitas variabel kepuasan kerja (Y1)

\begin{tabular}{lll}
\hline Keterangan & Nilai Perolehan & Tingkat Validitas \\
\hline Y1.1 & 0,331 & 0,3 \\
Y1.2 & 0,856 & 0,3 \\
Y1.3 & 0,843 & 0,3 \\
Y1.4 & 0,632 & 0,3 \\
\hline
\end{tabular}

Sumber: data diolah 2020

Berdasarkan output pada tabel di atas, dari keseluruhan item yang digunakan pada variabel kepuasan kerja perolehan nilai t hitungnya berada d iatas 0,3 , sehingga dapat dikatakan item 1 sampai 4 adalah valid.

Tabel 4. Hasil uji validitas variabel kinerja pegawai (Y2)

\begin{tabular}{ccc}
\hline Keterangan & Nilai Perolehan & Tingkat Validitas \\
\hline Y2.1 & 0,865 & 0,3 \\
\hline Y2.2 & 0,846 & 0,3 \\
Y2.3 & 0,759 & 0,3 \\
Y2.4 & 0,750 & 0,3 \\
\hline
\end{tabular}

Sumber: data diolah 2020

Berdasarkan output pada tabel di atas, dari keseluruhan item yang digunakan pada variabel kinerja pegawai perolehan nilai t hitungnya berada di atas 0,3 , sehingga dapat dikatakan item 1 sampai 4 adalah valid.

\section{2) Uji Reliabilitas}

Tabel 5.. Hasil uji reliabilitas

\begin{tabular}{ll}
\hline Keterangan & Cronbach's Alpha \\
\hline Karakteristik Pekerjaan (X1) & 0,819 \\
Motivasi Kerja (X2) & 0,745 \\
Kepuasan Kerja (Y1) & 0,634 \\
Kinerja Pegawai (Y2) & 0,810 \\
\hline Sumber: data diolah 2020 &
\end{tabular}

Dari tabel output di atas, hasil uji reliabilitas terhadap data yang gunakan dalam penelitian ini menunjukkan perolehan nilai cronbach's Alpha berada di atas 
ketentuan yakni lebih besar dari 0,6 sehingga dapat dikatakan bahwa item pertanyaan dari kuesioner dalam penelitian ini adalah bersifat relibel.

\section{3) Uji Hipotesis}

Tabel 6. Hasil uji hipotesis.

\begin{tabular}{llllll}
\hline & \multicolumn{3}{l}{$\begin{array}{l}\text { Unstandardized } \\
\text { Coefficients }\end{array}$} & \multirow{2}{*}{ t } & \multirow{2}{*}{ Sig. } \\
\cline { 2 - 3 } Keterangan & \multicolumn{3}{l}{ B } & & \\
\hline Karak. Pekerjaan (X1) terhadap Kep. Kerja (Y1) & 0,163 & 0,124 & & 3,314 & 0,006 \\
Motiv. Kerja (X2) terhadap Kep. Kerja (Y1) & 0,580 & 0,165 & & 3,513 & 0,001 \\
Karak. Pekerjaan (X1) terhadap Kiner. Pegawai (Y2) & 0,410 & 0,111 & & 3,687 & 0,001 \\
Motiv. Kerja (X2) terhadap Kiner. Pegawai (Y2) & 0,091 & 0,148 & & 0,616 & 0,541 \\
Kep. Kerja (Y1) terhadap Kiner. Pegawai (Y2) & 0,444 & 0,108 & & 4,117 & 0,000 \\
\hline Sumber: data diolah 2020 & & & & &
\end{tabular}

Dari tabel di atas dapat di simpulkan bahwa :

a. Variabel karakteristik pekerjaan (X1) mempunyai pengaruh terhadap variabel kepuasan kerja (Y1), hal ini dapat dilihat dari perolehan nilai t hitung di mana nilai dari t hitung sebesar 3,314 lebih besar dari t tabel sebesar 2,014. Dan perolehan nilai signifikansi sebesar 0,006 $<0,05$. Sedangkan untuk arah pengaruh diperoleh adalah positif sebesar 0,163. Sehingga dapat disimpulkan bahwa variabel karakteristik pekerjaan (X1) mempunyai pengaruh positif dan signifikan terhadap variabel kepuasan kerja (Y1), atau hipotesis pertama dalam penelitian ini di terima.

b. Variabel motivasi kerja (X2) mempunyai pengaruh terhadap variabel kepuasan kerja (Y1), hal dapat dilihat dari perolehan nilai dari t hitung sebesar 3,513> 2,014, dengan tingkat signifikansi sebesar 0,001<0,05, dengan arah hubungan positif sebesar 0,580. Sehingga dapat disimpulkan bahwa variabel motivasi kerja (X2) mempunyai pengaruh positif dan signifikan terhadap variabel kepuasan kerja (Y1), sehingga hipotesis kedua dalam penelitian ini diterima.

c. Variabel karakteristik pekerjaan (X1) mempunyai pengaruh terhadap variabel kinerja pegawai (Y2), hal ini dapat dilihat dari perolehan nilai sebesar 3,687 > 2,014. Dengan tingkat signifikansi sebesar 0,001 < 0,05 dengan arah hubungan positif sebesar 0,410. Sehingga dapat disimpulkan bahwa variabel karakteristik pekerjaan (X1) mempunyai pengaruh positif dan signifikan terhadap variabel kinerja pegawai (Y2) dalam hal ini hipotesis ke tiga dalam penelitian ini di terima. 
d. Variabel motivasi kerja (X2) tidak berpengaruh terhadap variabel kinerja pegawai (Y2) dengan perolehan nilai t hitung sebesar 0,616 2,014, dengan tingkat signifikansi sebesar 0,541>0,05. Dengan arah hubungan positif, sehingga dapat disimpulkan bahwa variabel motivasi kerja (X2) tidak mempunyai pengaruh terhadap variabel kinerja pegawai (Y2) sehingga terjadi penolakan terhadap hipotesis ke empat dalam penelitian ini.

e. Variabel kepuasan kerja (Y1) mempunyai pengaruh terhadap variabel kinerja pegawai (Y2), hal ini dapat dilihat dari perolehan nilai sebesar 4,117 > 2,014, dengan tingkat signifikansi sebesar $0,000<0,05$, dengan arah hubungan positif sebesar 0,444. Sehingga dapat disimpulkan bahwa variabel kepuasan kerja (Y1) mempunyai pengaruh positif dan signifikan terhadap variabel kinerja pegawai (Y2), dalam hal ini hipotesis ke lima dalam penelitian ini diterima.

Pengaruh variabel karakteristik pekerjaan (X1) terhadap kepuasan kerja (Y1) pegawai Balai Riset dan Standardisasi Industri Samarinda.

Dari hasil uji analisis, diperoleh hasil bahwa variabel karakteristik pekerjaan (X1) mempunyai pengaruh positif terhadap variabel kepuasan kerja (Y1) pegawai Balai Riset dan Standardisasi Industri Samarinda, berdasarkan dari perolehan nilai yang ada dimana nilai thitung sebesar 3,314 > dibandingkan dengan nilai ttabel serta dengan tingkat signifikan sebesar $0,006<0,05(5 \%)$. Hasil penelitian ini mengindikasikan bahwa bentuk sebuah pekerjaan atau karakteristik pekerjaan dapat memberikan pengaruh terhadap kepuasan kerja bagi pegawai Balai Riset dan Standardisasi Industri Samarinda. Kepuasan kerja pegawai Baristand Industri Samarinda tergambar dari jawaban responden pada pertanyaan X1.3 yaitu pekerjaan yang dilakukan menunjang keberhasilan organisasi dimana sebanyak 26 responden menjawab sangat setuju dan 22 responden menjawab setuju. Pegawai merasa kontribusi dari pelaksanaan pekerjaan yang dilakukan selama ini baik di bidang riset maupun pelayanan publik mampu membawa organisasi/ unit kerja mencapai tujuan dari visi dan misinya, dimana salah satu indikator keberhasilan unit kerja yaitu diperolehnya predikat sebagai unit kerja mempunyai kinerja terbaik selama 2 tahun berturut-turut. Selain itu pegawai merasa bahwa kompetensi mapun keahlian yang dimiliki telah sesuai dengan bidang penempatannya sehingga mampu 
menyelesaikan dengan baik terhadap tugas dan pekerjaan yang diberikan.

\section{Pengaruh variabel motivasi kerja (X2) terhadap variabel kepuasana kerja (Y1) Balai Riset dan Standardisasi Industri Samarinda.}

Hasil penelitian ini mengindikasikan bahwa kepuasan kerja yang diperoleh oleh seorang pegawai dapat disebabkan oleh beberapa faktor, antara lain adanya motivasi kerja, motivasi dalam hal ini muncul dari pihak pimpinan atau atasan dalam mendukung pegawai untuk bekerja, motivasi menjadi salah satu faktor yang dapat memberikan kepuasan dalam bekerja bagi seorang pegawai, karena dengan adanya motivasi akan mendorong pegawai untuk bekerja maksimal karena adanya harapan memperoleh sesuatu apabila pegawai tersebut bekerja dengan baik, motivasi ini muncul dari atasan yang memberikan sesuatu kepada pegawai yang mempunyai pekerjaan yang maksimal, motivasi kerja dapat berupa adanya imbalan yang akan diperoleh apabila pekerjaan yang dibebankan dapat diselesaikan dengan maksimal, peningkatan kompetensi pegawai, atau pemberian fasilitas pendukung yang memadai dalam melaksanakan pekerjaan. Hasil penelitian ini juga dapat dilihat dari jawaban respon terhadap pernyataan yang digunakan dalam penelitian ini dari 49 responden sebagian besar responden memberikan jawaban setuju dan sangat setuju terhadap pernyataan yang untuk variabel motivasi kerja, dimana salah satunya terhadap pernyataan yang memiliki rata-rata tertinggi pada X2.2 yaitu hubungan kerjasama antara rekan kerja terjalin dengan baik diperoleh nilai 4,347 dimana sebanyak 26 responden menjawab setuju dan sebanyak 20 responden menjawab sangat setuju. Hubungan kerjasama antar rekan kerja pegawai Baristand Industri Samarinda yang selama ini terjalin dengan baik tidak terlepas dari upaya pimpinan yang dibangun melalui kegiatan-kegiatan pengembangan capacity building terhadap seluruh pegawai yang diselenggarakan setiap tahun salah satunya melalui kegiatan outbond. Melalui kegiatan outbond dapat mempererat dan memperbaiki hubungan dan kerjasama antar pegawai. Selain hubungan kerjasama antar rekan kerja yang terjalin dengan baik, adanya imbalan yang diterima telah sesuai dengan tanggung jawab dan beban kerja merupakan salah satu motivasi kerja yang mempengaruhi terhadap kepuasan kerja, tergambar dari hasil jawaban responden sebanyak 30 responden menjawab setuju dan 17 responden menjawab 
sangat setuju. Pegawai Baristand Industri Samarinda selain menerima gaji setiap bulannya juga menerima tunjangan kinerja yang besarannya sesuai dengan grading berdasarkan jenjang jabatan yang melekat dimasing-masing pegawai. Besaran tunjangan kinerja tersebut akan mengalami perubahan seiring beban kerja yang dilakukan dengan ditandai perubahan jenjang jabatan. Faktor lain dari motivasi yang mempengaruhi kepuasan kerja adalah kesempatan yang diberikan untuk meningkatkan prestasi dan aktualisasi diri, dimana sebanyak 34 responden menjawab setuju dan 11 responden menjawab sangat setuju. Begitu pula untuk pernyataan pekerjaan yang dilakukan setiap pegawai dapat meningkatkan kedudukan atau posisi, dimana sebanyak 33 responden menjawab setuju dan 11 responden menjawab sangat setuju. Hasil penelitian dari jawaban responden tersebut mengindikasikan bahwa salah satu motivasi kerja yang diberikan adalah kesempatan untuk berprestasi dan aktualisasi diri mampu meningkatkan kepuasan kerja pegawai terlihat adanya keikutsertaan pegawai pada ajang kompetisi sesuai tupoksinya yang diselenggarakan oleh Kementerian Perindustrian seperti pemilihan arsiparis terbaik, pegawai teladan maupun kompetisi terkait inovasi litbang. Selain itu juga telah dilakukan promosi untuk menduduki jabatan lebih tinggi bagi seorang pegawai yang mempunyai kinerja bagus dan loyalitas yang tinggi terhadap institusi.

\section{Pengaruh variabel karakteristik pekerjaan (X1) terhadap variabel kinerja pegawai (Y2) Balai Riset dan Standardisasi Industri Samarinda}

Hasil uji analisis terhadap data dalam penelitian ini diperoleh bahwa variabel karakteristik pekerjaan (X1) mempunyai pengaruh positif dan signifikan terhadap kinerja pegawai (Y1) Balai Riset dan Standardisasi Industri Samarinda. Hasil tersebut dapat dilihat dari perolehan nilai dalam uji analisis statistik dimana nilai thitung sebesar 3,687 > dibandingkan dengan nilai ttabel serta dengan tingkat signifikan sebesar 0,001 $<0,05(5 \%)$. Hasil penelitian ini mengindikasikan bahwa karakteristik dari sebuah pekerjaan dapat meningkatkan kinerja bagi seorang pegawai, hal ini tergambar dari hasil penilaian responden dengan nilai rata-rata tertinggi pada pertanyaan X1.3 yaitu pekerjaan yang dilakukan menunjang keberhasilan organisasi/ unit kerja dengan nilai sebesar 4,510, dimana dari 49 responden yang menjawab setuju sebanyak 22 responden dan yang menjawab 
sangat setuju sebanyak 26 responden serta hanya 1 responden yang menjawab kurang setuju. Hal ini dapat dilihat dari keberhasilan Baristand Industri Samarinda dalam memperoleh predikat kinerja terbaik pertama tingkat eselon 1 Kementerian Perindustria selama 2 tahun berturut turut (tahun 2017 dan tahun 2018) serta terbaik kedua tahun 2019. Keberhasilan organisasi ini tidak terlepas dari kinerja pegawai yang saling mendukung antar bagian terutama dalam pemberian layanan jasa ke masyarakat maupun industry. Selain itu ditunjang juga dengan salah satu faktor adalah pemberian beban pekerjaan sesuai dengan bidang keahlian dan kemampuan yang dimiliki, sehingga pegawai akan menyelesaikan pekerjaan tersebut dengan hasil yang maksimal baik dari segi hasil maupun dari segi waktu, sehingga di harapkan kepada para atasan dapat mengedepankan dalam penempatan pegawai melihat bidang keahlian yang dimiliki oleh setiap pegawai, sehingga pegawai tersebut tidak akan merasa berat dalam bekerja dan tidak perlu lagi beradaptasi terhadap pekerjaan yang menjadi tanggung jawabnya. Pada instansi. Balai Riset dan Standardisasi Industri Samarinda telah menerapakan Sistem Manajemen Mutu SNI/ISO 9001: 2015, SNI/ISO 17025 : 2017 (untuk laboratorium) dan SNI/ISO 17065:2012 (untuk Lembaga Sertifikasi Produk) sebagai dasar dalam memberikan pelayanan kepada pihak konsumen. Dari hasil kuesioner yang di sebarkan di peroleh bahwa 24 responden memberikan jawaban setuju terhadap pernyataan bahwa atasan akan memberikan respon dari hasil pekerjaan yang di berikan dan 21 responden memberikan jawaban sangat setuju, hal ini mengindikasikan bahwa atasan selalu memberikan sebuah pekerjaan pada orang yang memang mempunyai keahlian yang sesuai dengan bidang pekerjaan yang di bebankan. Dan sebanyak 22 responden mejawab setuju serta 26 responden menjawab sangat setuju, hal ini mengindikasikan bahwa pegawai menjadi salah satu faktor utama keberhasilan sebuah oragnisasi sehingga penempatan pegawai harus sesuai dengan bidang keahlian dengan tujuan untuk memberikan hasil signifikan terhadap sebuah pekerjaan baik dari segi hasil maupun dari segi waktu penyelesaian. Lingkup pekerjaan yang terdapat pada Balai Riset dan Standardisasi Industri Samarinda membutuhkan keahlian khusus, sehingga dalam penempatan pegawai dan penerimaan pegawai harus memperhatikan spesifikasi bidang pekerjaan di 
sesuaikan dengan bidang keahlian yang dimiliki pegawai dan calon pegawai. Dengan adanya kesesuaian antara bidang keahlian terhadap beban kerja akan berdampak terhadap kinerja yang akan di berikan oleh setiap pegawai.

\section{Pengaruh variabel motivasi kerja (X2) terhadap variabel kinerja pegawai (Y2) Balai Riset dan Standardisasi Industri Samarinda.}

Dari hasil uji analisis terhadap data yang ada, diperoleh hasil bahwa variabel motivasi kerja (X1) tidak berpengaruh signifikan terhadap variabel kinerja pegawai (Y2) Balai Riset dan Standardisasi Industri Samarinda, hal ini berdasarkan dengan perolehan nilai t hitung sebesar 0,616 $<2,014$, dengan tingkat signifikansi sebesar $0,541>0,05$. Hasil penelitian ini mengindikasikan bahwa motivasi kerja yang diberikan kepada bawahan belum dapat meningkatkan kinerja pegawai pada Balai Riset dan Standardisasi Industri Samarinda, sehingga dapat dikatakan masih terdapat faktor lain yang lebih meningkatkan kinerja pegawai itu sendiri. Hal ini dapat dilihat dari penilaan responden terhadap pertanyaan ditiap indikator motivasi kerja sebanyak 14 responden menjawab kurang setuju, dimana pertanyaan X2.3 yaitu pekerjaan yang dilakukan dapat meningkatkan kedudukan/ posisi pegawai terbanyak menjawab kurang setuju yaitu sebanyak 5 reponden. Penilaian responden terhadap promosi jabatan di Baristand Industri Samarinda tidak sepenuhnya didasarkan pada kinerja pegawai didasarkan pada posisi Baristand Industri Samarinda sebagai Unit Pelayanan Teknis eselon 3, dimana untuk jabatan struktural sangat terbatas sehingga sebagian besar pegawai lebih memilih jalur jabatan fungsional. Bentuk dari motiviasi kerja tentunya berbagai macam antara lain pemberian reward terhadap pegawai yang bekinerja baik dan juga pemberian fasilitas yang memadai dalam mendukung pegawai dalam bekerja, karena dengan adanya motivasi kerja yang diharapkan oleh pegawai dapat mendorong seorang pegawai untuk bekerja dengan maksimal. Hasil penelitian ini juga dapat di ketahui dari jawaban responden terhadap pernyataan ketersediaan sumber daya organisasi yang dapat digunakan setiap pegawai dalam bekerja, sebanyak 29 responden memberikan jawaban setuju dan sebanyak 16 responden menjawab sangat setuju, hasil ini mengindikasikan bahwa organisasi telah memberikan fasilitas yang memadai dalam menunjang pekerjaan para pegawai dalam beraktifitas, dengan 
semakin lengkapnya peralatan yang di butuhkan akan memudahkan pegawai dalam bekerja dan tentunya akan meningkatkan kinerja pegawai dalam bekerja

\section{Pengaruh variabel kepuasan kerja (Y1) terhadap variabel kinerja pegawai} (Y2) Balai Riset dan Standardisasi Industri Samarinda.

Hasil uji analisis diperoleh bahwa variabel kepuasan kerja (Y1) mempunyai pengaruh positif signifikan terhadap variabel kinerja pegawai (Y2) Balai Riset dan Standardisasi Industri Samarinda yang dibuktikan dari perolehan nilai sebesar $4,117>2,014$, dengan tingkat signifikansi sebesar $0,000<0,05$. Hasil penelitian ini mengindikasikan bahwa dengan adanya rasa puas yang di peroleh oleh pegawai akan berdampak terhadap kinerja dalam bekerja, sehingga menjadi salah satu yang harus diperhatikan oleh pihak atasan atau pimpinan, bagaimana menciptakan rasa puas bawahan dalam melakukan sebuah pekerjaan, rasa puas yang diperoleh bawahan dapat dilihat dari berbagai aspek, diantaranya adalah puas akan lingkungan kerja dan fasilitas yang diberikan dalam bekerja, dan juga dalam menduduki posisi dimana posisi yang diberikan sesuai dengan bidang keahlian yang dimiliki, sehingga dengan begitu pegawai akan bekerja dengan maksimal dan berdampak terhadap kinerja yang dihasilkan. Faktor kepuasan dalam bekerja menjadi salah satu faktor dalam meningkatkan kinerja pegawai, karena rasa puas akan muncul dari seorang pegawai dalam bekerja apabila apa yang di butuhkan terpenuhi, salah satunya adalah terjalinnya Kerjasama yang baik antara tim atau teman sejawat dalam menyelesaikan sebuah pekerjaan, sebanyak 34 responden memberikan jawaban puas dan 10 responden memberikan jawaban sangat puas terhadap penyataan tersebut. Selain itu juga kondisi lingkungan pekerjaan menjadi salah satu faktor munculnya rasa puas pegawai yang dapat meningkatkan kinerja pegawai, sebanyak 31 responden memberikan jawaban puas serta 12 responden memberikan jawaban sangat puas dengan kondisi lingkungan kerja yang mendukung dalam bekerja.

\section{Kesimpulan}

Dari hasil uji analisis dan pembahasan yang telah dilakukan pada bab sebelumnya, maka terdapat beberapa kesimpulan yang dapat diambil: 
1) Variabel karakateristik pekerjaan (X1) mempunyai pengaruh positif signifikan terhadap variabel kepuasan kerja (Y1) pegawai Balai Riset dan Standardisasi Industri Samarinda. Hal ini mengindikasikan bahwa karakateristik dari pekerjaan yang di berikan oleh pimpinan kepada bawahan berdampak terhadap kepuasan kerja pegawai hal ini dapat dipengaruhi oleh salah satunya adalah telah sesuainya antara bidang keahlian pegawai dengan beban kerja yang diberikan.

2) Variabel motivasi kerja (X2) mempunyai pengaruh positif dan signifikan terhadap variabel kepuasan kerja (Y1) pegawai Balai Riset dan Standardisasi Industri Samarinda. Hal ini mengindikasikan bahwa motivasi kerja menjadi salah satu faktor yang dapat memberikan kepuasan terhadap pegawai, motivasi yang diberikan dapat berupa imbalan baik berbentuk materi maupun non materi serta fasilitas yang memadai sesuai dengan pekerjaan yang dibebankan.

3) Variabel karakteristik pekerjaan (X1) mempunyai pengaruh terhadap kinerja pegawai (Y2) Balai Riset dan Standardisasi Industri Samarinda. Hal ini menggambarkan bahwa dengan menempatkan seorang pegawai sesuai dengan bidang keahlian yang dimiliki akan berdampak terhadap kinerja pegawai dalam bekerja, karena dengan penempatan yang sesuai dengan bidang ilmu yang dimiliki, tentunya pegawai akan bekerja dengan maksimal sesuai dengan beban kerja yang diberikan.

4) Variabel motivasi kerja (X2) tidak berpengaruh terhadap kinerja pegawai (Y2) Balai Riset dan Standardisasi Industri Samarinda. Hal ini mengindikasikan bahwa motivasi kerja yang diberikan oleh pimpinan terhadap bawahan belum mampu meningkatkan kinerja pegawai, dengan motivasi yang diberikan diharapkan dapat memberikan dampak positif terhadap kinerja yang dihasilkan, namun dalam penelitian ini terjadi sebaliknya, sehingga dapat disimpulkan bahwa motivasi yang di berikan oleh pimpinan terhadap bawahan pada instansi Balai Riset dan Standardisasi Industri Samarinda, belum sesuai dengan apa yang diinginkan pegawai.

5. Variabel kepuasa kerja (Y1) mempunyai pengaruh terhadap variabel kinerja pegawai (Y2) Balai Riset dan Standardisasi Industri Samarinda. Hal ini 
mengindikasikan bahwa dengan merasa puasnya pegawai terhadap pekerjaan akan berdampak terhadap peningkatan kinerja pegawai tersebut, rasa puas bagi seorang pegawai dapat berupa kondisi lingkungan kerja yang memadai, serta lingkungan kerja yang konndusif dan ketidak terbatasnya kesempatana yang diberikan oleh pimpinan terhadap pegawai tersebut dalam mengeksplore diri dalam menyelesaikan sebuah pekerjaan.

\section{DAFTAR PUSTAKA}

Bintoro, D. (2017). Manajemen penilaian kinerja karyawan. Yogyakarta: Gava Media.

Hasibuan, M. S. P., \& Hasibuan, H. M. S. P. (2016). Manajemen sumber daya manusia. Bumi Aksara.

Kinicki, A., \& Kreitner, R. (2006). Organizational behavior: Key concepts, skills \& best practices. McGraw-Hill/Irwin New York.

Mulyadi, A. (2018). First Responder Emergency Training Dan Perilaku Petugas Satuan Pengamanan Dalam Penanganan Korban Kegawatdaruratan. Jurnal Keperawatan Terapan (e-Journal), 4(1), 6-13.

Mulyani, S., \& Soliha, E. (2014). Pengaruh karakteristik pekerjaan dan motivasi terhadap komitmen organisasional serta dampaknya terhadap kinerja guru. Performance, 20(2).

NEGARA, K. P. A., BIROKRASI, D. A. N. R., \& INDONESIA, R. (2014). Pedoman Survei Kepuasan Masyarakat Terhadap Penyelenggaraan Pelayanan Publik. Jakarta.

Siagian, S. P. (2005). Manajemen Sumber Daya Manusia, Cetakan XII, PT. Bumi Aksara, Jakarta.

Siagian, S. P. (2017). Manajemen sumber daya manusia. Bumi Aksara.

Subudi, M., Riana, I. G., \& Juniari, N. K. E. (2015). Pengaruh Motivasi terhadap Kepuasan Kerja dan Kinerja Pegawai Negeri Sipil (Pns) di Sekolah Tinggi Pariwisata Nusa Dua Bali. E-Jurnal Ekonomi Dan Bisnis Universitas Udayana, 4, 44774.

Susilo, W. (2002). Securing handheld devices. Proceedings 10th IEEE International Conference on Networks (ICON 2002). Towards Network 
Superiority (Cat. No. 02EX588), 349-354.

Wibowo, N. (2016). Upaya peningkatan keaktifan siswa melalui pembelajaran berdasarkan gaya belajar di SMK Negeri 1 Saptosari. Elinvo (Electronics, Informatics, and Vocational Education), 1(2), 128-139. 